Original article

\title{
Biomonitoring for iron, manganese, chromium, aluminum, nickel and cadmium in workers exposed to welding fume: a preliminary study
}

\author{
Mulyana ${ }^{1,3,4}$, Mierna Reismala ${ }^{2}$, Cynthia Nikopama ${ }^{2}$, Afriyanti Wulandari ${ }^{2}$, Ferry Chandra ${ }^{2}$, \\ Tri Nevita Panjaitan ${ }^{1,3}$, Dorethea Krisiana ${ }^{3}$, Marlisawati Sukma ${ }^{3}$, Indah Rachmawati ${ }^{3}$, Tri Agus Purnomo ${ }^{3}$, \\ Dina Ratnawati ${ }^{3}$, Wahyu Purwita Sari ${ }^{3}$, Vani Nur Pratami ${ }^{4}$, Bertha Pangaribuan ${ }^{2,3}$ \\ ${ }^{1}$ Hasanuddin University, Makassar, South Sulawesi, Indonesia \\ ${ }^{2}$ Universitas Indonesia, Jakarta, Jakarta Capital Region, Indonesia \\ ${ }^{3}$ Prodia Occupational Health Institute, Jakarta Capital Region, Indonesia \\ ${ }^{4}$ Padjadjaran University, Bandung, West Java, Indonesia
}

Received 9 February 2015, Accepted 19 February 2015

(C) 2015, Mulyana, Reismala M., Nikopama C., Wulandari A., Chandra F., Panjaitan T.N., Krisiana D., Sukma M., Rachmawati I., Purnomo T.A., Ratnawati D., Sari W.P., Pratami V.N., Pangaribuan B.

(C) 2015, Russian Open Medical Journal

Abstract: The control of exposure to welding fumes is increasing importance in promoting a healthy, safe and productive work environment. This study is a case-control design, random study was conducted among welder (56 subjects) and non welder (39 subjects) with more than 1 years experience in the same job task in an automotive parts manufactory within the industrial area at Cikarang in 2013. All subjects were completed physical examination, informed consent and questionnaire. Blood heavy metals were determined by Inductively-Coupled Plasma Mass Spectrometry (ICP-MS). Whole blood iron, manganese, chromium and lead in welder were higher than non-welder, but not different for aluminum, nickel and cadmium. In welder, chromium and manganese correlated with smoking status, cadmium correlated with age and smoking status. In multivariate analysis, wholeblood cadmium correlates with age and smoking status.

Keywords: biomonitoring, welding fumes, heavy metals, working period, smoking status

Cite as Mulyana, Reismala M, Nikopama C, Wulandari A, Chandra F, Panjaitan TN, Krisiana D, Sukma M, Rachmawati I, Purnomo TA, Ratnawati D, Sari WP, Pratami VN, Pangaribuan B. Biomonitoring for iron, manganese, chromium, aluminum, nickel and cadmium in workers exposed to welding fume: a preliminary study. Russian Open Medical Journal 2015; 4: e0202.

Correspondence to Mulyana. E-mail: arsenicosa10@gmail.com

\section{Introduction}

Welding is a common process used to join metals by heating them to welding temperature by heating them to welding temperature [1]. Welding processes produce hazardous agents including fumes, gases, vapors, heat, noise and ultraviolet and infrared radiation. The fumes generated during welding are considered to be the most harmful compared with other byproducts of welding. Welding fumes consist of metal oxide particles and gases that are formed during welding. The particles are small enough to become and remain airborne and are easily inhaled. Although it is almost impossible to consume enough iron oxide to cause a toxic effect [2], steel contains alloying elements that, in their pure forms, could be hazardous to the worker's health. Welding fumes can induce adverse health effects, such as neurological [3] and respiratory problems [1, 4]. The National Institute of Occupational Safety and Health (NIOSH) concluded that there is an elevated risk of lung cancer among welders that cannot be completely accounted for by smoking or asbestos exposure [5]. More recent papers also support the view that welding fumes could increase the risk of lung cancer $[6,7]$.
Post exposure to welding fumes (including inhalation and dermal absorption) could be reflected by their levels in biological fluids; nevertheless, their presence does not by itself mean causing diseases or adverse effects [8]. In order to evaluate a possible exposure to organic and inorganic contaminants blood is commonly employed in human biomonitoring, nevertheless it does not trace the bio-accumulated chemicals [9]. Human biomonitoring is defined as the direct measurement of people's exposure to environmental contaminants by measuring substances or their metabolites in blood, urine, or other specimens. The great strength of bio-monitoring is that it provides unequivocal evidence that both exposure and uptake have taken place [8]. At present, many bio-monitoring investigations have been conducted at international level in population-based surveys designed as a basis for protecting public health [10].

Blood and urine samples are the most widely used and accepted matrices for bio-monitoring heavy metal exposure in occupational and environmental toxicology. Blood has the undeniable advantage that it is in contact with all tissues and in equilibrium with organs and tissues. Therefore, it has been used extensively for various research and survey goals. However, blood 
sampling is an invasive procedure and suffers from ethical and practical constraints, particularly for small children or other susceptible populations [11].

In this study, a human bio-monitoring program was carried out on the levels of iron, manganese, chromium, cadmium, nickel and lead in blood of welder and non welder. Blood was previously acid lysed and the elements were all quantified by means of inductively coupled plasma mass spectrometry (ICP-MS). This paper presents and discusses the outcome of this study.

\section{Material and Methods}

\section{Population study}

This case-control design, random study was conducted among welder ( 56 subjects) and non welder (39 subject) with more than 1 years experience in the same job-task in an automotive parts manufactory within the industrial area at Cikarang in the end 2013. The participating subjects were all welder who were willing to participate in the study which meet the inclusion criteria and non-welder from the same factory.

The inclusion criteria were: (1) welder aged between 18-55 years; (2) agreed to undergo bio-monitoring test, and (3) agreed to fill the informed consent form. The data collected consisted of structured interview with questionnaire to inquire several information, such as bio-data, smoking status and date of birth. Local ethic committee of Faculty of Medicine, Universitas Indonesia has approved the study protocol and gave permission to perform this study.

\section{Biological sample collection, sample treatment, and analysis}

After the interview, a blood sample of at least $3 \mathrm{~mL}$ was also obtained from each subject (Vacuette Blod Collection Needle, $38 \times$ $0.9 \mathrm{~mm}$, and Vacuette EDTA Tube $3 \mathrm{~mL}$, Greiner Bio-One, Germany). Biological samples were transported in a portable cooler $\left(2-8{ }^{\circ} \mathrm{C}\right)$ to Prodia Occupational and Environmental Health Laboratory, JIn Kramat Raya No53 Jakarta, and frozen at $-30{ }^{\circ} \mathrm{C}$ before analysis. Complete analysis of the biological samples was performed by inductively-coupled plasma mass spectrometry.

\section{Instrumentation}

Throughout the following study, an Agilent 7700s with an integrated sample introduction system for discrete sampling (ISISDS) and helium collision mode were used. The instrument was equipped with MassHunter Workstation Revision B.01.01 for instrument control and data handling software. The ICP-MS was operated with $\mathrm{Ni}$ sampler and skimmer cones, MicroMist glass concentric nebulizer and quartz Scott-type spray chamber.

\section{Reagents}

Plasma torch argon purity was higher than $99.99 \%$ (Linde Gas, Jakarta, Indonesia). Water was purified with Mili-Q D1 water (Merck Millipore, Darmstadt, Germany). Trace-Select ${ }^{\circledR}$ nitric acid $>69 \%$ (Fluka, ST. Louis, USA), triton-X and multi-element standard solution (30 elements) (Merck, Darmstadt, Germany). The diluent solution used in this method is 1:1 an aqueous solution of $0.1 \%$ triton-X 100 and nitric acid $0.4 \%$. Diluent solution will be used in the preparation of all calibrators and samples during the dilution process just prior to analysis.

\section{Sample preparation}

Method for sample preparation according Goull et al [13], with modification. Briefly, frozen whole bloods were thawed at room temperature \pm 1 hour. After homogenization, $150 \mu \mathrm{L}$ whole blood was diluted 1: 20 with diluent solution up to $3000 \mu \mathrm{L}$, and homogenized. The limit of detection was $364.77 \mu \mathrm{g} / \mathrm{L}$ for iron, $0.46 \mu \mathrm{g} / \mathrm{L}$ for manganese, $0.05 \mu \mathrm{g} / \mathrm{L}$ for chromium, $3.12 \mu \mathrm{g} / \mathrm{L}$ for aluminum, $0.19 \mu \mathrm{g} / \mathrm{L}$ for nickel, $0.05 \mu \mathrm{g} / \mathrm{L}$ for cadmium and $0.18 \mu \mathrm{g} / \mathrm{L}$ for lead, respectively.

\section{Statistical analysis}

Normality of data distribution was tested with the SmirnovKolmogorov test. The differences in quantitative variables were tested with the parametric $t$ test or Mann-Whitney as alternative test, depending on whether the data were normally distributed or not. The non-parametric Spearman rank correlation test was used to investigate the relationship between concentrations of iron, manganese, chromium, aluminum, nickel, cadmium, lead, age, years in employment and smoking status in welder. Correlations with a Spearman correlation coefficient ( $\rho$ ) higher than 0.600 were considered strong and those with a Spearman correlation coefficient ranging from 0.300 to 0.599 were considered medium [12]. Statistical analyses were performed with SPSS, version 11.5. In all statistical analyses, two-sided $P$ values of 0.05 were considered significant.

\section{Results}

The general characteristics of the studied population are summarized in Table 1. In total, 95 subjects were involved in this study. The average of age of the welder group was significantly lower than non-welder group. Persentage of male and working period ( $<5$ years) of welder group were higher than non-welder group.

The distribution of iron, manganese, chromium, aluminum, nickel, cadmium and lead in whole blood in our study population is shown in Table 2. Because values did not follow a normal distribution the medians and ranges of the data for each element are presented. Whole-blood iron, manganese, chromium and lead were higher in welder group than non welder group. Iron, manganese, chromium and lead were different significanly.

Table 3 present data for the bivariate analyses among metal concentration in whole blood, age, working period and smoking status among welder. Wholeblood manganese and chromium level correlate with smoking status. Wholeblood cadmium level correlate with age and smoking status.

Table 1. Characteristics of study participants

\begin{tabular}{lccc}
\hline \multicolumn{1}{c}{ Parameters } & $\begin{array}{c}\text { Welder } \\
(n=56)\end{array}$ & $\begin{array}{c}\text { Non welder } \\
(n=39)\end{array}$ & P-value \\
\hline Age, years, mean (min-max) & $23.61(18-42)$ & $30.08(18-41)$ & $<0.001$ \\
Male sex, $\mathrm{n}(\%)$ & $56(100.0)$ & $30(76.92)$ & $<0.001$ \\
Working period <5 years, $\mathrm{n}(\%)$ & $39(69.64)$ & $7(17.95)$ & $<0.001$ \\
Smoking status, $\mathrm{n}(\%)$ & & & $>0.05$ \\
- Current & $33(58.92)$ & $9(23.08)$ & \\
- Former & $0(0.0)$ & $6(15.38)$ & \\
- Non smoker & $23(41.07)$ & $24(61.54)$ & \\
\hline
\end{tabular}


Table 2. Heavy metal levels in wholeblood from the study population

\begin{tabular}{|c|c|c|c|}
\hline Variable & Welder $(n=56)$ & Non welder $(n=39)$ & P-value \\
\hline Iron, Fe $(\mu \mathrm{g} / \mathrm{L})$ & $291.878,60(237.721,05-384.174,62)$ & $273.431,34(193.898,49-362.605,05)$ & $0.011^{*}$ \\
\hline Manganese, Mn ( $\mu \mathrm{g} / \mathrm{L})$ & $17.52(1.73-52.90)$ & $8.66(1.89-22.12)$ & $0.000 *$ \\
\hline Chromium, $\mathrm{Cr}(\mu \mathrm{g} / \mathrm{L})$ & $1.67(0.38-6.35)$ & $1.07(0.04-5.92)$ & $0.002^{*}$ \\
\hline Aluminum, $\mathrm{Al}(\mu \mathrm{g} / \mathrm{L})$ & 35.95 (1.24 - 111.18) & 33.26 (7.98 - 129.68) & 0.745 \\
\hline Nickel, Ni ( $\mu \mathrm{g} / \mathrm{L})$ & $0.47(0.21-2.79)$ & $0.54(0.23-1.36)$ & 0.212 \\
\hline Cadmium, Cd ( $\mu \mathrm{g} / \mathrm{L})$ & $0.90(0.28-7.59)$ & $1.17(0.30-6.21)$ & 0.063 \\
\hline Lead, $\mathrm{Pb}(\mu \mathrm{g} / \mathrm{L})$ & $45.12(25.39-99.75)$ & $37.97(18.82-76.51)$ & $0.002^{*}$ \\
\hline
\end{tabular}

$*$ is Mann Whitney test. Data presented as median (minimum-maximum).

Table 3. Spearman rank correlation coefficients ( $\rho$ ) for the correlation between levels of heavy metal level in wholeblood, age, working period and smoking status in welder

\begin{tabular}{|c|c|c|c|c|c|c|c|}
\hline & $\mathrm{Fe}$ & $M n$ & $\mathrm{Cr}$ & $A l$ & $\mathrm{Ni}$ & $C d$ & $\mathrm{~Pb}$ \\
\hline Age & -0.050 & -0.019 & 0.195 & 0.023 & -0.073 & $0.282^{\#}$ & -0.070 \\
\hline Working period & -0.117 & -0.028 & 0.046 & -0.073 & 0.059 & 0.246 & 0.02 \\
\hline Smoking status & -0.250 & $0.405^{*}$ & $-0.270^{\#}$ & 0.145 & 0.221 & $0.273^{\#}$ & -0.091 \\
\hline
\end{tabular}

" is $\mathrm{P}<0.05 ;{ }^{*}$ is $\mathrm{P}<0.01$.

Table 4. Multiple linear regression analysis of metal concentration (logtransformed)

\begin{tabular}{|c|c|c|c|c|}
\hline Element & $\operatorname{adj} R$ & Predictor & $B$ & $P$-value \\
\hline \multirow[t]{2}{*}{ Cadmium } & 0.155 & Age & 0.297 & 0.022 \\
\hline & & Smoking status & 0.269 & 0.037 \\
\hline
\end{tabular}

Table 4 shows multiple linear regression analyses for cadmium wholeblood level (log transformed), adjusted for age and smoking status. The latter covariate entered into models only when a statistically significant correlation was found in the bivariate analyses (Table 3).

\section{Discussion}

Human biological monitoring has become an important tool in environmental and occupational health for the assessment of internal exposure to harmful substances and to evaluate temporal changes in populations exposed to a defined environmental contaminant [14]. Biomonitoring has become increasingly important for the establishment of occupational and environmental limits of exposure of metal ions and has contributed to reduce exposure and to prevent adverse health effects [15]. This study has assessed the usefulness of less invasive biological samples, using blood, for biomonitoring the internal dose of individuals occupationally exposed to heavy metals. The simultaneous biomonitoring of iron, manganese, chromium, aluminum, cadmium and led in wholeblood using ICPMS, because some toxic metals have trace quantity [13].

Wholeblood Iron, manganese, chromium and lead level in welder were higher than non welder. These findings are consistent with the composition of welding rod. Iron level welder is higher than non welder, unfortunately no guidelines of reference value and biological matrices for iron biomonitoring. Iron level was not correlated with age, smoking status and working period. Iron deposition in the lung and airway associate with tissue injury and fibrosis. Iron is one of the source for oxidative stress in the lung [16]. Free iron in the lung exerts toxic effects through its ability to catalyse highly reactive hydroxyl radicals from less reactive superoxide and hydrogen peroxide via the Fenton and HaberWeiss reaction, and/or through its ability to stimulate fibrogenesis [17].
In our study, however, the median of wholeblood manganese level of $17.52 \mu \mathrm{g} / \mathrm{L}$ in welder and $8.66 \mu \mathrm{g} / \mathrm{L}$ in non welder. based on reference [18], 28 subjects in welder group (50.0\%) have wholeblood manganese level higher than $14 \mu \mathrm{g} / \mathrm{L}$; and 8 sujects $(20.5 \%)$ in non-welder, respectively. Wholeblood manganese level may reflect the total body burden of manganese, which accumulate over the years of welding practice, one would expect to see a higher wholeblood manganese concentration in welders with a longer employment history. Data presented in this report, revealed that wholeblood manganese levels were not significantly associated with working period. The lack of such an association is not unexpected because a discrepancy between blood half life ( $t 1 / 2)$ and tissue $t 1 / 2$ of manganese has been documented in several studies $[19,20]$. The intracellular distribution and tight tissue binding of manganese likely contribute to the difference between blood and tissue t1/2. Wholeblood manganese level correlated with smoking status. In Indonesia, manganese cigarrette level has not been published, but in another country, manganese level is very high, 90.28- $106.23 \mathrm{mg} / \mathrm{kg}$ [21].

Wholeblood chromium level in welder $1.67(0.38-6.35) \mathrm{ug} / \mathrm{L}$ is higher than non welder 1.07 (0.04 - 5.92). This finding is consistent with earlier study [15]. The chromium level was measured as total chromium, because we did not use speciation ICPMS technique. Wholeblood chromium level correlated with smoking status. Another study determines heavy metals in cigarrette, including chromium with geometric mean $2.35 \mu \mathrm{g} / \mathrm{g}$ cigarrette [22]. Chromium is a polyvalent metal, in the body chromium has 2 oxidation number, $3+$ and $6+$. Chromium $3+$ occurs in trace amounts in foods and waters, and appears to be benign. Chromium deficiency, involving a lack of Chromium 3+ in the body, or may some complex of it, such as glucose tolerance factor is controversial, or is at least extremely rare. However, other reviews have regarded it as an essential trace element in humans [23]. In contrast, chromium $\mathrm{Cr}^{6+}$ is very toxic and mutagenic substance [24]. Determination chromium $6+$ in welder is more useful in welder biomonitoring.

Wholeblood aluminum and nickel in welder did not significant differented than non welder. Aluminum level in wholeblood was influenced by antacid consumption [25]. In another study, serum also was used as biomatrix with lack correlation [26]. Total body burden of aluminum in healthy individuals is $30-50 \mathrm{mg}$, 
approximately $50 \%$ of the body burden is in the skeleton and $25 \%$ is in the lungs. Aluminum can be measured in the blood, bone, urine, and feces, but there are insufficient data to relate aluminum exposure levels with blood or urine levels. Aluminum measured in feces cannot be used to estimate absorption [27]. In humans, about $20-35 \%$ of inhaled nickel deposited in the lungs is absorbed into the bloodstream. Nickel is not metabolized and absorbed nickel is eliminated via urine. ATSDR recommend serum or urine as biological matrix in biomonitoring program [28].

In welding process, paint is the source of lead and cadmium. In our study, wholeblood cadmium level have a higher tendency in nonwelder. 2 person of non-welder have higher cadmium level than $5 \mu \mathrm{g} / \mathrm{L}$ [29] with smoking status more than 12 cigarette per day. Consistent with earlier study, increasing wholeblood cadmium level significantly correlated with age [30] and smoking status [31,32]. Wholeblood lead level in welder is higher 45.12 (25.39 99.75) than non welder (37.97 (18.82 - 76.51). Age, smoking status and working period not correlated with blood lead level.

In biomonitoring program, heavy metal determination is very useful as biomarker of exposure and ICPMS accommodate this program. Smoking status, working period, food intact and type of biological matrix must be considered.

\section{Conclusion}

Our data indicate that heavy metal determination in blood, can be used for biomonitoring program in worker expose to welding fumes. in our preliminary study, we not have any welding air data in manufacturing area, and can not conducted the correlation between biomonitoring data and source of exposure. However, more research is needed to ascertain whether or not these matrix offer definitive advantages.

\section{Acknowledgments}

We would like to thank the Prodia Education and Research Institute, Sub-Dept. Occupational Health Faculty of Medicinie Universitas Indonesia and Prodia Occupational Health Institute for their invaluable supports to this research.

Conflict of interest: No conflict of interest.

\section{References}

1. Antonini JM, Santamaria AB, Jenkins NT, Albini E, Lucchini R. Fate of manganese associated with the inhalation of welding fumes: potential neurological effects. Neurotoxicology 2006; 27: 304-310. (PMID: 16219356)

2. Antonini JM, Krishna-Murthy GG, Rogers RA, Albert R, Eagar TW, Ulrich $\mathrm{GD}$, et al. How welding fumes affect the welder, a study helps reveal how certain welding fumes affect our lungs. Welding J 1998; 77: 5559.

3. Yu IJ, Park JD, Park ES, Song KS, Han KT, Han JH, et al. Manganese distribution in brains of Sprague-dawley rats after 60 days of stainless steel welding-fume exposure. Neurotoxicology 2003; 24: 777-785. (doi: 10.1016/S0161-813X(03)00046-9)

4. Yoon CS, Paik NW, Kim JH. Fume generation and content of total chromium and hexavalent chromium in flux-cored arc welding. Ann Occup Hyg 2003; 47: 671-680. (doi: 10.1093/annhyg/meg063)

5. Centers for Disease Control. Publication of NIOSH criteria documents on welding, and brazing, thermal cutting and on radon progeny. MMWR Morb Mortal Wkly Rep 1998; 37: 545-547.

6. Sørensen AR, Thulstrup AM, Hansen J, Ramlau-Hansen $\mathrm{CH}$, Meersohn A, Skytthe A, et al. Risk of lung cancer according to mild steel and stainless steel welding. Scand J Work Environ Health 2007; 33: 379386. (doi: 10.5271/sjweh.1157)
7. Ambroise D, Wild P, Moulin JJ. Update of a meta-analysis on lung cancer and welding. Scand J Work Environ Health 2006; 32: 22-31. (doi: 10.5271/sjweh.973)

8. Needham LL, Calafat AM, Barr DB. Uses and issues of biomonitoring Int J Hyg Environ Health 2007; 210: 229-38. (PMID: 17157561)

9. Smolders R, Schramm KW, Nickmilder M, Schoeters G. Applicability of non-invasively collected matrices for human biomonitoring. Environ Health 2009; 8: 8. (doi: 10.1186/1476-069X-8-8)

10. Pirkle JL, Osterloh J, Needham LL. Sampson EJ. National exposure measurements for decisions to protect public health from environmental exposures. Int J Hyg Environ Health 2005; 208: 1-5. (doi: 10.1016/j.jjheh.2005.01.001)

11. Esteban M, Castano A. Non-invasive matrices in human biomonitoring A review. Environ Int 2009; 35: 438-444. (doi: 10.1016/j.envint.2008.09.003)

12. Artusi R, Verderio $P$, Marubini E. Bravais-Pearson and Spearman correlation coefficients: meaning, test of hypothesis and confidence interval. Int J Biol Markers 2002;17:148-151. PMID: 12113584

13. Goullé JP, Mahieu L, Castermant J, Neveu N, Bonneau B, Lainé G, et al. Metal and metalloid multi-elementary ICP-MS validation in whole blood, plasma, urine and hair. Reference values. Forensic Sci Int 2005 4; 153: 39-44. (doi: 10.1016/j.forsciint.2005.04.020)

14. Nunes JA, Batista BL, Rodrigues JL, Caldas NM, Neto JAG, Barbosa Jr F. A simple method based on ICP-MS for estimation of background levels of arsenic, cadmium, cooper, manganese, nickel, lead and selenium in blood of the brazilian population. J Toxicol Environ Health A 2010; 73 878-887. (doi: 10.1080/15287391003744807)

15. Gil F, Hernández AF, Márquez $C$, Femia $P$, Olmedo $P$, López-Guarnido $\mathrm{O}$, et al. Biomonitorization of cadmium, chromium, manganese, nicke and lead in wholeblood, urine, axillary hair and saliva in an occupationally exposed population. Sci Total Environ 2011; 409: 11721180. (doi: 10.1016/j.scitotenv.2010.11.033) (PMID: 21211822)

16. Mumby S, Chung KF, McCreanor JE, Griffiths MJD, Quinlan GJ. Prooxidant iron in exhaled breath condensate: a potential excretory mechanism. Respir Med 2011; 105: 1290-1295. (doi: 10.1016/j.rmed.2011) (PMID: 21514132)

17. Mateos F, Brock JH, Pérez-Arellano JL. Iron metabolism in the lower respiratory tract. Thorax 1998; 53: 594-600. (PMID: 9797761)

18. Deutsche Forschungsgemeinschaft. Weinheim, Deuts. Biologische Arbeitsstoff-Toleranz-Werte (BAT-Werte), Expositionsäquivalente für krebserzeugende Arbeitsstoffe (EKA), BiologischeLeitwerte (BLW) und Biologische Arbeitsstoff-Referenzwerte (BAR) -Arbeitsmedizinischtoxikologische Begründungen. 2013, 1983-2012.

19. Zheng W, Kim H, Zhao Q. Comparative toxicokinetics of manganese chloride and methylcyclo-pentadienyl Mn tricarbonyl in male SpragueDawley rats. Toxicol Sci 2000; 54: 295-301. (doi: 10.1093/toxsci/54.2.295) (PMID: 10774811)

20. Takeda A, Sawashita J, Okada S. Biological half-lives of zinc and manganese in rat brain. Brain Res 1995; 695: 53-58. (PMID: 8574647)

21. Iwuoha GN, Oghu EI, Onwuachu UI. Levels of selected heavy metals in some brands of cigarettes marketed in University of Port Harcourt, Rivers State. J Appl Sci Environ Manag 2013; 17: 561-564. (doi: 10.4314/jasem.v17i4.13)

22. Caruso RV, O'Connor RJ, W. Stephens E, Cummings KM, Fong GT. Toxic metal concentrations in cigarettes obtained from U.S. smokers in 2009: results from the International Tobacco Control (ITC) United States Survey Cohort. Int J Environ Res Public Health 2014; 11: 202 217. (doi: 10.3390/ijerph110100202) (PMID: 24452255)

23. Anderson RA. Chromium as an essential nutrient for humans. Reg Toxicol Pharmacol 1997; 26: S35-S41. (doi: 10.1006/rtph.1997.1136) (PMID: 9380836)

24. Cheng L, Sonntag DM, de Boer J, Dixon K. Chromium(VI)-induced mutagenesis in the lungs of big blue transgenic mice. J Environ Pathol Toxicol Oncol 2000; 19: 239-249. (PMID: 10983890) 
25. Sharp CA, Perks J, Worsfold M, Day JP, Davie MW. Plasma aluminum in a reference population: the effects of antacid consumption and its influence on biochemical indices of bone formation. Eur J Clin Invest 1993; 23: 554-550. (PMID: 8243526)

26. Riihimäki V, Valkonen $S$, Engström B, Tossavainen A, Mutanen $P$, Aitio A. Behavior of aluminum in aluminum welders and manufacturers of aluminum sulfate-impact on biological monitoring. Scand J Work Environ Health 2008; 34: 451-462. (doi: 10.5271/sjweh.1291) (PMID: 19137207)

27. Agency for Toxic Subtances and Disease Registry. Atlanta, U.S: Toxicological profile for aluminum. 2008; 12 p.

28. Agency for Toxic Subtances and Disease Registry. Atlanta, U.S: Toxicological profile for nickel, 2005; $125 \mathrm{p}$.

29. American College Government Industrial Health. Cincinnati, U.S: Threshold limit value and biological exposure indices, 2008; 103 p.

30. Olsson IM, Bensryd I, Lundh T, Ottosson H, Skerfving S, Oskarsson A. Cadmium in blood and urine impact of sex, age, dietary intake, iron status, and former smoking--association of renal effects. Environ Health Perspect 2002; 110: 1185-1190. (PMID: 12460796)

31. Martin CJ, Antonini JM, Doney BC. A case report of elevated blood cadmium. Occup Med 2009; 59: 130-132. doi: 10.1093/occmed/kqn163. (PMID: 19147796)

32. Galazyn-Sidorczuk M, Brzóska MM, Moniuszko-Jakoniuk J. Estimation of Polish cigarettes contamination with cadmium and lead, and exposure to these metals via smoking. Environ Monit Assess 2008; 137: 481-493. (PMID: 17508260)

Authors:

Mulyana - B.Sc. Pharm., MHSc, PhD Student, Faculty of Medicine, Hasanuddin University, Makassar, South Sulawesi, Indonesia; Occupational and Environmental Laboratory Head, Prodia Occupational Health Institute, Jakarta, Indonesia; Clinical Pharmacy Staff, Faculty of Pharmacy, Padjadjaran University, Bandung, Indonesia.

Mierna Reismala - MD, Master Student in Occupational Medicine, Faculty of Medicine, Universitas Indonesia, Jakarta, Indonesia.

Cynthia Nikopama - MD, Master Student in Occupational Medicine, Faculty of Medicine, Universitas Indonesia, Jakarta, Indonesia.

Afriyanti Wulandari - MD, Master Student in Occupational Medicine, Faculty of Medicine, Universitas Indonesia, Jakarta, Indonesia.

Ferry Chandra - MD, Master Student in Occupational Medicine Faculty of Medicine, Universitas Indonesia, Jakarta, Indonesia.

Tri Nevita Panjaitan - B.Sc. Pharm., MHSc, Bussiness Development Deputy Manager, Prodia Occupational Health Institute, Jakarta, Indonesia.

Dorethea Krisiana - B.Sc., Occupational Laboratory Technologist, Prodia Occupational Health Institute, Jakarta, Indonesia.

Marlisawati Sukma - B.Sc.HSE, Health and Safety Staff, Prodia Occupational Health Institute, Jakarta, Indonesia.

Indah Rachmawati - B.Sc., Occupational Laboratory Technologist, Prodia Occupational Health Institute, Jakarta, Indonesia.

Tri Agus Purnomo - B.Sc., Occupational Laboratory Technologist, Prodia Occupational Health Institute, Jakarta, Indonesia.

Dina Ratnawati - B.Sc., Occupational Laboratory Technologist, Prodia Occupational Health Institute, Jakarta, Indonesia.

Wahyu Purwita Sari - B.Sc. Pharm., Quality Assurance Supervisor, Prodia Occupational Health Institute, Jakarta, Indonesia.

Vani Nur Pratami - B.Sc. Pharm., Clinical Pharmacy Staff, Faculty of Pharmacy, Padjadjaran University, Bandung, Indonesia.

Bertha Pangaribuan - Ph.D, Occupational Medicine Staff, Faculty of Medicine, Universitas Indonesia, Jakarta, Indonesia; General Manager, Prodia Occupational Health Institute, Jakarta, Indonesia. 